\title{
Realizacija projekata baziranih na konceptu „pametnih“ gradova u Hrvatskoj s osvrtom na grad Jastrebarsko
}

\section{Implementation of projects based on the concept of „smart" cities in Croatia - the city of Jastrebarsko case study}

\section{Tamara Slišković}

Doc.dr.sc.

Ekonomski fakultet

Sveučilišta u Zagrebu

E-mail: tamara.sliskovic@efzg.hr

\section{Ivona Vrhovec}

E-mail:ivrhovec@net.efzg.hr
Ključne riječi: pametni grad, pametna rješenja, koncept pametnih gradova, pametna infrastruktura

JEL klasifikacija: 018, 030, R39

\section{Abstract}

The application of advanced technology has completely transformed citizens, cities and communities, creating an intelligent and smart society. First of all, it is necessary to point out the importance of applying innovative solutions tailored to the needs of cities and citizens. By using innovative approaches, cities are able to improve the economic picture and make urban life a more convenient and better place to live. The article analyses the process of implementing certain components of smart cities in Croatia. The aim of the article is to explore the concept of a smart city, their structure and function and to analyse smart solutions in the application of the concept of smart cities in Croatia, with special reference to the city of Jastrebarsko. Quantitative research was applied through a questionnaire $(n=129)$ in the Jastrebarsko area. The results of the research show the involvement of Croatian cities in the process of implementation of smart solutions and the positive impact of new urban governance methods, which enable interactive, inclusive and innovative urban systems, solve urban development dilemmas, ensure residents' needs, continuously optimise and improve, and ultimately achieve sustainable urban development.

Keywords: smart city, smart solutions, smart cities concept, smart cities infrastructure JEL classification: 018,030, R39

\section{Tamara Slišković, PhD}

Asst. prof.

Faculty of Economics and Business, University of Zagreb E-mail: tamara.sliskovic@efzg.hr

\section{Ivona Vrhovec}

E-mail: ivrhovec@net.efzg.hr 
Slišković, T., Vrhovec, I.

Realizacija projekata baziranih na konceptu „pametnih“ gradova u Hrvatskoj s osvrtom na grad Jastrebarsko

\section{Uvod}

U današnjem svijetu, ljudi uživaju u svim pogodnostima koje je donio napredak znanosti i tehnologije. S razvojem gospodarstva i poboljšanjem životnog standarda, zahtjevi građana neprestano se povećavaju. Ne samo da populacija ljudi raste iz dana u dan, nego se i javlja potreba za boljom kvalitetom života. Porastom gradova, javlja se i potreba za razvojem infrastrukture i usluga te je nužno osvrnuti se na potrebe građana.

Gradovi su suočeni s brojnim izazovima, poput starenja infrastrukture, klimatskih promjena i onečišćenja okoliša uzrokovanih lošom prometnom infrastrukturom ili lošom kvalitetom zgrada. Važan aspekt je pronalazak inteligentnih rješenja kako bi gradovi mogli u potpunosti iskoristiti ogroman potencijal infrastrukture. Pametna infrastrukturna rješenja poput pametnih mreža, automatizacije zgrada i inteligentnih prometnih sustava gradova zahtijevaju integraciju različitih pametnih inicijativa za poboljšanje kvalitete života stanovnika i promicanje gospodarskog rasta. Pametna rješenja za gradove pružaju informacije i znanje kao temeljne resurse i koriste informacijsku tehnologiju nove generacije kao potporno sredstvo za izgradnju pametnog grada. Korištenjem napredne informacijske tehnologije omogućavaju se bolji uvjeti za život u urbanoj sredini.

S druge strane, važan aspekt u razvoju pametnih gradova predstavlja jačanje digitalne svijesti putem uključivanja i sudjelovanja građana u digitalnoj transformaciji društva i grada. Za nastanak pametnog grada je, osim ulaganja u infrastrukturu i digitalnu tehnologiju, potrebno građanima pružiti adekvatnu edukaciju kako bi im se omogućile bolje usluge za kvalitetu života te se na taj način postigao bolji gospodarski rast kroz izgradnju uspješne zajednice. Cilj ovog članka je ukazati na važnost implementacije pametnih rješenja u gradove općenito, ali i u Hrvatskoj. Kada se govori o pametnim rješenjima, u ovom radu se prvenstveno podrazumijevaju čimbenici koji se odnose na pametno gospodarstvo, pametan okoliš, pametnu mobilnost, pametno upravljanje, pametan život i pametne ljude (Giffinger i sur., 2007.).

Predmet ovog članka je obrazložiti značenje riječi „pametno“ u kontekstu gradova i rješenja koja je potrebno implementirati u gradove kako bi se poboljšala kvaliteta života. Da bi se detaljno obrazložio koncept pametnih gradova i realiziranih projekata baziranih na tom konceptu, potrebno je prvenstveno objasniti pojam pametnog grada. Potrebno je ustanoviti koja su sva moguća pametna rješenja i kako funkcionira njihova primjena u gradovima. Analizom postojećih gradova u Hrvatskoj definirano je ono što čini grad pametnim gradom. Identificiraju se čimbenici i koraci u strategiji pametnog grada te se važnost strategije grada javlja kao prvi korak prema razvitku pametnog grada. Predmet ovog istraživanja temelji se na strateškim pristupima i realizaciji pametnih rješenja. Pametni gradovi trebali bi se fokusirati, prije svega, na poboljšanje kvalitete života građana i s time usko vezana pitanja za zaštitu okoliša i zdravlja ljudi. Kao glavni cilj članka postavlja se istraživanje koncepta pametnoga grada i analiziranje pametnih rješenja u primjeni koncepta pametnih gradova na području Hrvatske, s posebnim osvrtom na grad Jastrebarsko. U svrhu analize, primijenjeno je kvantitativno istraživanje putem anketnog upitnika ( $n=129)$ na području grada Jastrebarsko.

\section{Teoretska podloga}

\subsection{Koncept pametnog grada}

Pametni gradovi predstavljaju pametan način donošenja odluka za cijeli grad. Čitav grad je osmišljen u procesu njegovog planiranja i izvršenja. Kako bi se grad smatrao pametnim gradom, potrebno je prije svega razviti „smart city“ strategiju. Tu strategiju je potrebno prilagoditi potrebama i interesima pojedinog grada i njegovih građana. Strategija uvijek ima određeni slijed. U tom smislu, prvenstveno se definiraju teme koje se na određeni način, određenom dinamikom i određenim sredstvima mogu implementirati.Potom se predlažu glavna funkcionalna područja u kojima gradovi moraju napredovati kako bi postigli status pametnog grada. Kako bi se dosegla ta područja, uzimaju se u obzir izvješća, rad i perspektive različitih javnih subjekata i tijela, lokalnih uprava, privatnih subjekata ili javno-privatnih organizacija uključenih u razvoj pametnih gradova.

Na temelju rada Europskog projekta Smart City, kao i brojnih drugih izvora u postojećoj literaturi (vidjeti, 
Slika 1. Obilježja pametnih gradova

\begin{tabular}{|c|c|c|}
\hline $\begin{array}{l}\text { Pametno gospodarstvo } \\
\text { (kompetitivnost) }\end{array}$ & $\begin{array}{c}\text { Pametni ljudi } \\
\text { (društveni i ljudski kapital) }\end{array}$ & $\begin{array}{l}\text { Pametna uprava } \\
\text { (participacija) }\end{array}$ \\
\hline $\begin{array}{l}\text { - } \text { inovativnost } \\
\text { - poduzetništvo } \\
\text { - gospodarska slika i zaštitni znak } \\
\text { - međunarodna prepoznatljivost } \\
\text { - fleksibilnost radne snage } \\
\text { - produktivnost } \\
\text { - } \text { sposobnost transformacije }\end{array}$ & $\begin{array}{l}\text { - sklonost cjeloživotnom obrazo- } \\
\text { vanju } \\
\text { - socijalni i etnički plurizam } \\
\text { - kozmopolitizam/ otvorenost } \\
\text { - participacija u društvenom životu } \\
\text { - razina kvalifikacije } \\
\text { - fleksibilnost } \\
\text { - kreativnost }\end{array}$ & $\begin{array}{l}\text { - sudjelovanje u donošenju odluka } \\
\text { - političke strategije i perspektive } \\
\text { - javni i socijalni servisi } \\
\text { - transparentna uprava }\end{array}$ \\
\hline Pametna mobilnost & $\begin{array}{l}\text { Pametan okoliš } \\
\text { (prirodni resursi) }\end{array}$ & $\begin{array}{l}\text { Pametan život } \\
\text { (kvaliteta života) }\end{array}$ \\
\hline $\begin{array}{l}\text { - } \text { dostupnost infrastrukture } \\
\text { - održiv, inovativan i siguran sustav } \\
\text { prijevoza } \\
\text { - lokalna dostupnost } \\
\text { - (inter)nacionalna dostupnost }\end{array}$ & $\begin{array}{l}\text { - atraktivnost prirodnih uvjeta } \\
\text { - upravljanje održivim izvorima } \\
\text { - zaštita okoliša } \\
\text { - smanjenje zagađenja }\end{array}$ & $\begin{array}{l}\text { - kulturne ustanove } \\
\text { - zdravstveni uvjeti } \\
\text { - individualna sigurnost } \\
\text { - kvaliteta stanovanja } \\
\text { - obrazovne ustanove } \\
\text { - turistička atraktivnost } \\
\text { - socijalna kohezija }\end{array}$ \\
\hline
\end{tabular}

Izvor: obrada autora prema podacima izvješća Europske inicijative za pametne gradove: Smart Cities - Ranking of European medium-sized cities (11.7.2020.), str. 12.

primjerice Giffinger i sur., (2007.), Giffinger, Kramar i Haindl (2010.) Schuurman i sur.,(2012.), Batty i sur., (2012.)), grad se smatra pametnim gradom ukoliko ima barem jedan čimbenik koji se odnosi na jedan ili više sljedećih obilježja: pametno gospodarstvo, pametni ljudi, pametna uprava, pametna mobilnost, pametan okoliš te pametan život. Navedenih šest obilježja, kao i njima dodijeljeni čimbenici koji čime grad pametnim detaljnije su prikazani na Slici 1.

Nakon što je definirano područje djelovanja i njemu pripadajuće djelatnosti, sljedeći korak je utvrđivanje glavnih usluga na kojima bi trebalo poduzeti mjere za kretanje prema pametnom gradu. Glavni cilj primjene koncepta pametnog grada je poboljšanje učinkovitosti javnih usluga grada koje mogu unaprijediti kvalitetu života građana, a među glavne glavni korisnike rezultata spada i lokalna uprava. Smart City je, dakle, grad koji postavlja svoje prioritete pametnom strategijom, rezultatom vježbe razmišljanja, u kojem glavna socijalna i gospodarska tijela određuju model grada u koji žele evoluirati te definirati i dati prednost inicijativama koje će im omogućiti da postignu taj model.
Te inicijative kao osnovni stup imaju uporabu informacijskih i komunikacijskih tehnologija (IKT), koje omogućuju optimiziranje upravljanja urbanim infrastrukturama i uslugama, kao i uslugama koje se pružaju građanima, a sve s ciljem održivog i inteligentnog razvoja.

Stvaranje pametnih gradova je višedimenzionalni i sustavni projekt, koji zahtijeva visoku razinu međusobne povezanosti urbanog planiranja i pametne gradske IT infrastrukture. Razina komunikacijske i informacijske tehnologije te napredna i praktična razina povezane infrastrukture nisu jedine mjere pametnih gradova, te postoje i mnogi drugi važni pokazatelji (Atlee i Por, 2016.).U konačnici, dugoročni cilj je da pametni gradovi podignu životni standard ljudi, integriraju tehnologiju u društva i postignu održivi razvoj.

Kada je riječ o pametnim gradovima, ono o čemu zapravo govorimo je urbano okruženje. Prije svega, građani uvijek inzistiraju na dobroj kvaliteti života, koja je jedna od glavnih stavki u koju je potrebno uložiti napore kako bi grad dostigao status pametnog. Primjena napredne tehnologije potpuno
Slišković, T., Vrhovec, I.

Realizacija projekata baziranih na konceptu „pametnih“ gradova u Hrvatskoj s osvrtom na grad Jastrebarsko 
Slišković, T., Vrhovec, I.

Realizacija projekata baziranih na konceptu „pametnih“ gradova u Hrvatskoj s osvrtom na grad Jastrebarsko je promijenila građane, gradove, zajednice i uslužni rad, stvarajući inteligentno društvo. Tehnologija kao sustav omogućuje transformaciju cjelokupnog društva, stvara nove mogućnosti, a u konačnici poboljšava i svijet. Fizički svijet i digitalni svijet počeli su se približavati i međusobno surađivati.Uz pomoć velikih podataka, oblaka, analitike i mobilne tehnologije, sada se mogu automatski prikupljati i dijeliti podatci s objektima, umanjujući na taj način ljudsku intervenciju. $\mathrm{U}$ ovom visoko povezanom svijetu digitalni sustavi mogu snimati, nadzirati i prilagoditi svaku interakciju između umreženih stavki. Gradovi trebaju prije svega razumjeti kako iskoristiti vrijednost tih podataka za bolje donošenje odluka, za bolje projekte, bolju suradnju te za bolje povjerenje i transparentnost stvarajući na taj način zajednice koje dobro koriste podatke te pružaju bolje usluge.

Prema istraživanjima, Hrvatska se još uvijek smatra konzervativnim društvom kada je riječ o usvajanju novih tehnoloških ideja (Škrlec, 2017.), no hrvatski gradovi se polako okreću k digitalizaciji i optimizaciji usluga građana. Veliki broj hrvatskih, odnosno otprilike 40 do 128 gradova, razvija ili je razvilo koncept pametnog grada u nekom području primjene te je implementiralo ili je u procesu razvijanja pametnih rješenja. Rezultat istraživanja od strane Fakulteta za prometne znanosti u Zagrebu (Brčić i sur., 2017.) pokazao je da 51,7 \% hrvatskih gradova sudjeluje u cijelosti ili u nekim pojedinačnim projektima na temu pametnih gradova te izdvajaju ili planiraju izdvojiti određena financijska sredstva za provođenje koncepta pametnog grada.

\section{2. Čimbenici pametnog grada}

Kada se govori o pametnim gradovima i kada se izrađuju strategije pametnih gradova vidljivo je da postoje nizovi segmenata u kojima se identificiraju pametni gradovi. Na Slici 1. navedeni su čimbenici prema kojima se grad može smatrati pametnim. To su, redom: pametno gospodarstvo, pametni ljudi, pametna uprava, pametna mobilnost, pametan okoliš i pametni život.

Pametno gospodarstvo usredotočeno je na gospodarski i konkurentni razvoj grada koji se temelji na inovacijama, te obuhvaća čimbenike vezane za gospodarsku konkurentnost poput inovacija, poduzetništva, produktivnosti i fleksibilnosti tržišta rada kao i integraciju na (među)nacionalno tržište. Za cilj ima postizanje gospodarskog rasta i promicanje inovacija u djelatnostima turizma, trgovine i poslovanja, digitalnim poduzećima i sektorima za zapošljavanje i razvoj inovativnih rješenja. Pametno gospodarstvo uključuje ne samo gospodarstvo pojedinog grada, već vezu grada s drugim gradovima, odnosno globalno umreženo središte. Uključuje usluge i interakcije koje povezuju i, prema potrebi, integriraju javne, privatne i civilne zajednice kako bi grad mogao učinkovito funkcionirati kao jedan organizam.

Pametni ljudi nisu opisani samo razinom kvalifikacije ili obrazovanja, već i kvalitetom društvenih interakcija u pogledu integracije i javnog života i otvorenosti prema svijetu. Kvaliteta života građana, prije svega, postiže se participacijom građana u transformaciji društva, odnosno grada. Razvoj pametnih gradova sa svim tehnološkim unapređenjima, posebno kroz primjenu informacijsko-komunikacijske tehnologije, mora u znatno većoj mjeri biti otvoren prema društvenoj, emocionalnoj i duhovnoj strani čovjekova života (Burazer, 2012.). Pristup obrazovanju, ljudskim resursima i upravljanju kapacitetima, unutar inkluzivnog društva poboljšava kreativnost i potiče inovacije. Pametni ciljevi uključuju transparentnost i pristup podatcima korištenjem IKT-a i e-vlade u participativnom odlučivanju i e-uslugama. Informirani i aktivni građani predstavljaju srž pametnih gradova te se javlja potreba za stalnom edukacijom građana kako bi bili u mogućnosti unositi i koristiti podatke putem odgovarajućih alata za analizu podataka i nadzornih ploča. Putem stalne informiranosti građani lakše donose odluke te stvaraju proizvode i usluge te $s$ time direktno mogu utjecati na bolji gospodarski rast i kvalitetu života.

Upravljanje gradom podrazumijeva razvoj pametne uprave, podrazumijevajući ne samo nabavu opreme koja predstavlja sekundarno pitanje, nego i uvid stanja onoga s čime grad raspolaže, inventure podatkovnih mreža i uvođenje informacijske i komunikacijske tehnologije. Pametna uprava predstavlja transparentnu vladu koja se oslanja na tehnologiju kako bi postigla kvalitetu i učinkovitost 
u svojim uslugama. Pametno upravljanje usmjereno je na postizanje digitalne, otvorene i transparentne uprave, a koja obuhvaća tematike transparentnosti, sudjelovanja, digitalne uprave, strateškog planiranja i zemljopisne informacije grada. Sastoji se od aspekata političkog sudjelovanja, usluga za građane kao i funkcioniranja uprave. E-upravljanje obuhvaća kako načine koji objašnjavaju kako upravljati, služiti, organizirati i formulirati prijedloge povezane s svjetskim zajednicama koje se nastanjuju na urbanim područjima. Djelovanje je također usmjereno u razvoj tehnologija za promicanje sudjelovanja građana u različitim područjima, koje je u posljednjem desetljeću privlačilo pozornost zbog utjecaja na kvalitetu života (Ferro De Guimarães i sur., 2020:253).

U slučaju područja pametne mobilnosti temeljna svrha je evoluirati u povezani i pristupačni grad. Ovo područje obuhvaća promet i cestovnu infrastrukturu u korelaciji $s$ informacijskom infrastrukturom, uključujući platforme za velike podatke, električnu, vodovodnu i transportnu mrežu. Lokalna i međunarodna pristupačnost važni su aspekti pametne mobilnosti kao i dostupnost informacijskih i komunikacijskih tehnologija te modernih i održivih prometnih sustava. Održivi promet u gradovima zahtjeva posebnu inovativnost u pronalaženju rješenja koja su dovoljno mala i pristupačna, a opet dovoljno relevantna za gradove. Ono što je bitno je da se uoče realne potrebe gradova. Standardno se pod održivim prometom puno govori o prikupljanju velikih količina podataka u gradskom prometu putem kojih se onda regulira promet. To je nešto što je samo u najvećim hrvatskim gradovima dostupno i prihvatljivo. U drugim slučajevima može se govoriti o nekim manjim, parcijalnim rješenjima koja sudionicima u prometu daju kvalitetne informacije. Bilo da se radi o informacijama o dostupnim parkirnim mjestima ili da se radi o informacijama o dostupnim linijama javnog prijevoza javlja se potreba za primjenom održivih oblika prometa putem poticanja (elektro) mobilnosti i drugih po okolini manje štetnih vrsta prometa.

Pametno okruženje usmjereno je na promicanje održivog urbanog okruženja, koje uključuje pametne inicijative u područjima urbanog okoliša, gospodarenja otpadom te potrošnje energije i vode. Pametno okruženje opisano je atraktivnim prirodnim uvjetima, onečišćenjem, upravljanjem resursima i naporima u pravcu zaštite okoliša. Rastuće svjetsko stanovništvo donijelo je ozbiljne izazove, uključujući prijevoz, infrastrukturu, potražnju za zdravstvenim i sanitarnim uslugama i ekološka pitanja kao što su hrana, voda i opskrba energijom. „Pametno“ okruženje može omogućiti ljudima da budu napredni kad se suočavaju s tim problemima i izazovima.

Gradovi moraju stvoriti uvjete za održivi razvoj kroz sljedeće načine:

- Digitalna tehnologija postaje sve važnija, a urbana infrastruktura i zgrade moraju se planirati učinkovitije i održivije.

- Emisije ugljičnog dioksida trebale bi biti što je moguće niže, a gradovi to mogu postići ulaganjem u električna vozila i automobile bez vozača.

- Korištenjem pametne tehnologije za izgradnju infrastrukture koja štedi energiju i okolišu je prihvatljivija.

- Korištenjem pametnog osvjetljenja poput postavljanja razine svjetline i praćenja svakodnevne upotrebe kako bi se smanjili zahtjevi za napajanjem.

- Provođenjem rješenja za gospodarenje otpadom koja pomažu u optimizaciji učinkovitosti prikupljanja otpada, smanjenju operativnih troškova i boljem rješavanju ekoloških problema povezanih s neučinkovitim sakupljanjem otpada.

Područje gospodarenja energijom, zaštite okoliša, zaštite prirode i klimatskih promjena vrlo je bogato područje za koje je poželjno da gradovi razvijaju pametna rješenja, bilo da nabavljaju gotova rješenja ili implementiraju svoje. Hrvatski gradovi još uvijek nedovoljno razmišljaju o tom segmentu koji je od iznimne važnosti. Energetska učinkovitost, pametna rješenja o potrošnji i praćenju potrošnje energije i vode, prikupljanje podataka o okolišu i energetici trebaju postati dio svakodnevnice svakog grada. Također, važan aspekt predstavlja suradnja i interakcija s građanima te primjena zelene nabave, odnosno javne nabave koja preferira ekološki prihvatljiva i energetski održiva rješenja. Gradovi u Hrvatskoj imaju puno prostora za unaprjeđenje
Slišković, T., Vrhovec, I.

Realizacija projekata baziranih na konceptu „pametnih“ gradova u Hrvatskoj s osvrtom na grad Jastrebarsko 
Slišković, T., Vrhovec, I.

Realizacija projekata baziranih na konceptu „pametnih“ gradova u Hrvatskoj s osvrtom na grad Jastrebarsko praćenja i distribucije informacija o kvaliteti okoliša i trebaju to što prije iskoristiti i realizirati.

Čimbenik pametnog života počiva na tome da je polazište i cilj izgradnje pametnog društva ispunjavanje potreba ljudi, uključujući medicinsku njegu, obrazovanje, socijalnu sigurnost, prijevoz, zapošljavanje i mirovinske usluge te informacijske izvore i informacijsku tehnologiju. Putem tehnologije želi se postići ravnoteža usluga i homogenizacija te se želi poboljšati zadovoljstvo i sreća ljudi.

Sudjelovanje zajednice uključuje dva aspekta:

- Sudjelovanje u donošenju odluka, odnosno, sudjelovanje građana u formuliranju politike i provedbi vladinog odlučivanja te

- Ostvarivanje ciljeva socijalnog i održivog razvoja.

U konačnici, pametan grad primjenjuje inovativna rješenja za poboljšanje kvalitete života građana i pristupačnosti njegovih stanovnika te osigurava održiv gospodarski, socijalni i ekološki razvoj uz kontinuirano poboljšanje. Cilj je koristiti pametne metode za promicanje razvoja pametnih gradova. Sukladno tome, moraju se uzeti u obzir ljudska prava, zahtjevi i potrebe. Potrebno je uspostaviti interakciju grada s građanima na multidisciplinaran način i prilagoditi se njihovim potrebama, na način da se osigura učinkovitost u kvaliteti i troškovima.

\section{Mogućnosti za sufinanciranje pro- jekata primjene koncepta pametnih gradova}

Pojam „stopa sufinanciranja” odnosi se na doprinos financiranja EU programa. Iskazuje se kao postotak ukupnog troška programa. Sufinanciranje je obično podložno ograničenju maksimalne stope, što se definira kao postotak ukupne vrijednosti programa ili nekog njegova dijela. Komisija određuje stope sufinanciranja za svaki operacijski program (Ministarstvo regionalnoga razvoja i fondova Europske unije, 2018.).

Prijava na natječaj Fonda za zaštitu okoliša i energetsku učinkovitost jedna je od prvih prilika gdje potencijalni nosioci pametnih gradova i općina mogu financirati ideje za pametna rješenja i razvoj takvih ideja te njihovu implementaciju kroz javno financiranje. Cilj javnog poziva je bio da se sufinanciraju projekti koji primjenjuju koncept pametnih gradova i općina, odnosno financiranje inovativnog i učinkovitog pristupa upravljanja i provedbe poslova gradova.

Prihvatljiva područja za provedbu projekta (FZOEU, 2019.):

- gospodarstvo,

- poboljšanje sigurnosti građana i imovine,

- održivi promet,

- gospodarenje energijom, zaštita okoliša, klimatske promjene,

- upravljanje gradom ili općinom i uslugama,

- obrazovanje i kvaliteta života mladih.

Fond je dodjeljivao sredstva pomoći u tri grupe: sufinanciranje do 80 posto, 60 posto i 40 posto opravdanih troškova ukupne vrijednosti ulaganja u provedbu projekata. Prema izvješću Fonda za zaštitu okoliša i energetsku učinkovitost (FZOEU, 2019.) za sufinanciranje projekata primjene koncepta „pametnih gradova i općina“ od 258 ukupno zaprimljenih zahtjeva, samo 56 zahtjeva je ostvarilo sufinanciranje, što iznosi $21,7 \%$, dok čak 202 zahtjeva, odnosno 78,3\%, nisu ostvarili sufinanciranje od strane Fonda.Ukupno procijenjeni opravdani troškovi iznosili su 14.608.871,94 kn, dok je ukupno sudjelovanje Fonda iznosilo 7.984.495,38 kn. Najveći broj odobrenih zahtjeva bio je iz područja projekta upravljanja gradom ili općinama i uslugama. Radilo se 035 odobrenih projekata, odnosno $62,5 \%$. Nadalje, sufinancirano je sedam projekata iz područja obrazovanja i kvalitete života građana (12,5\%), šest projekta iz područja održivog gospodarenja energijom, zaštitom okoliša, prirode i klimatske promjene (10,71\%), pet projekata iz područja sigurnosti $(8,93 \%)$ te tri projekta iz područja održivog prometa $(5,36 \%)$.

Kao poticaj za što veća ulaganja u unaprjeđenja infrastrukture i inovativna tehnološka rješenja, već petu godinu zaredom organiziran je projekt „Pametni gradovi - gradovi budućnosti“ s ciljem razvoja digitalizacije i poticanja pametnih rješenja u pametnim gradovima,kao i podizanje opće svijesti građana 0 aktualnom stanju realizacije i provedbe rješenja usmjerenih na poboljšanje kvalitete života. Pametni gradovi - gradovi budućnosti zamišljen 
je kao polugodišnji projekt u kojem se u kampanji, kroz novinske priloge i specijal na internetskoj platformi upoznaje zajednica sa "smart city“ inicijativama u Hrvatskoj i u ostalim europskim zemljama, dostupnim tehnološkim rješenjima te relevantnim znanstvenim istraživačkim radovima. Završna faza projekta uobličena je u konferenciju, koja je ujedno i središnja manifestacija projekta, a održana je u studenome 2019. (Poslovni dnevnik, 2019.).

\section{Opis čimbenika pametnog grada u Jastrebarskom}

\subsection{Pametno gospodarstvo}

Kada govorimo o gospodarstvu u Republici Hrvatskoj, Fond za zaštitu okoliša i energetsku učinkovitost je definirao da se mogu financirati i inovativna rješenja i projekti vezani za jačanje infrastrukture koja jest podrška gospodarstvu i gospodarstvenicima. Postoji već dosta primjera dobre prakse u Hrvatskoj u primjeni različitih inovativnih rješenja u području turizma i kulture putem kojih se može dalje inspirirati i graditi digitalna transformacija poslova gradova ili općina usmjerenih na komunikaciju s poduzećima. Riječ je 0 različitim portalima i digitalnim servisima za podršku te informiranje gospodarstvenika na području grada ili općine. Educiranje poduzetnika i kvalitetno informiranje građana u gradu Jastrebarsko postaju dio svakodnevnice. U planu je otvaranje poduzetničkog inkubatora usmjerenog na razvoj gospodarstva i poduzetništva. Osnivanje inkubatora podrazumijeva organizaciju kontinuiranih edukacija poduzetnika za inovacije, održivo gospodarstvo i cirkularnu ekonomiju te digitalnu transformaciju, kao i održavanje edukacija za poduzetnike, obrtnike i poljoprivrednike u okviru kojih će se provoditi programi cjeloživotnog obrazovanja, inkubacijske radionice i seminari u svrhu olakšavanja pokretanja poslovanja te pružati savjetodavna i pravna pomoć (Jastrebarsko.hr, 2019.). U poduzetničkom inkubatoru dio će biti organiziran kao inovacijski centar u kojemu će biti održana razna predavanja i edukacije. Razvijene su i razne mobilne i Internet platforme s ciljem povezivanja OPG-ova i obrtnika te stvaranja skladnog poslovnog okruženja. Javlja se i primjena virtualne i proširene stvarnosti putem kojih je omogućen uvid u kulturnu i prirodnu baštinu Grada Jastrebarsko.

Kako bi se veza mogla uspostaviti, najbolji alat za postizanje toga je informacijsko-komunikacijska tehnologija (IKT) koji predstavlja iznimno važan dio suvremenog poslovanja. Istraživanje i razvoj IT poduzeća te alati za urbani sustav upravljanja s karakteristikama organskog povezivanja osnovni su način za izgradnju pametnog grada, za što je potrebna cjelokupna upotreba urbanog fizičkog prostora i resursa (IBM, 2020.). Pojam IKT posebno se odnosi na komunikacijsku tehnologiju, pametne uređaje poput pametnih telefona i tableta i druge komunikacijske medije putem kojih je omogućen stalni pristup internetu.

\subsection{Pametni ljudi}

Grad Jastrebarsko veliku važnost posvećuje edukaciji zaposlenika gradske uprave i građana. Posebna se važnost pridaje i korištenju informacijsko komunikacijske tehnologije i STEM području za djecu i mlade. Posljednjih godina Grad Jastrebarsko stvorio je čvrste temelje koji su snažan poticaj sugrađanima, onim najmlađima, kao i onim najstarijima da se nastavi podizati kvaliteta života kroz ono što je najbitnije sačuvati, a to je čist okoliš i baština zavičaja grada Jastrebarsko. Provedene su, ali se i dalje planiraju provoditi edukacije građana vezane za digitalizaciju. Plan je uvođenje interne e-learning platforme za informiranje građana, poticanje inovativnosti i povećanju poslovne izvrsnosti. Također, uvođenje raznih seminara i radionica iz STEM područja u planu je programa strategije. Potaknut uspjehom takvih radionica u drugim većim gradovima diljem Hrvatske, Grad želi proširiti edukacijske aktivnosti koje nudi u Centru za kulturu za djecu i mlade. (Jastrebarsko.hr, 2019.).

\subsection{Pametna uprava}

Grad Jastrebarsko brzo je prihvatio mogućnost pametnog rukovođenja i upravljanja terenskim radovima ili intervencijama tako da je svaka intervencija prostorno, vremenski i kategorijski evidentirana u sustavu kroz cijeli svoj razvojni ciklus. Na konferenciji „Pametni gradovi“, Grad Jastrebarsko je dobio priznanje u kategoriji Pametne uprave. Kandidirana su tri projekta: e-ceste, e-sjednice i info Jaska, na kojima rade već zadnjih sedam godina. To je rezultat investiranja
Slišković, T., Vrhovec, I.

Realizacija projekata baziranih na konceptu „pametnih“ gradova u Hrvatskoj s osvrtom na grad Jastrebarsko 
Slišković, T., Vrhovec, I.

Realizacija projekata baziranih na konceptu „pametnih“ gradova u Hrvatskoj s osvrtom na grad Jastrebarsko grada u programska rješenja i činjenica da su zajedno s programerima napravili ona rješenja koja su najbolja za grad Jastrebarsko. To priznanje je bilo i poticaj za daljnji rad. Implementirana su brojna pametna rješenja popute-usluga i unaprjeđenje web stranice Grada Jastrebarskog. E-usluge grupirane su prema djelatnostima kao što su: e-Pravni poslovi, e-Komunalne djelatnosti i e-Društvene djelatnosti. Također, u procesu realizacije su i e-usluge za podršku poduzetnicima i poljoprivrednicima. Putem gradskog portala, osim e-usluga, građanima je dan uvid u informacije i obavijesti vezane za Grad Jastrebarsko te im je omogućena direktna komunikacija s gradskom upravom kroz e-forum Valja istaknuti uslugu e-stipendiranje koja je u tijeku realizacije. Putem usluge e-stipendiranje Grad Jastrebarsko želi potaknuti obrazovanje na način da najboljim učenicima olakša financijski teret studija, uz istovremeno uključivanje lokalnih poduzeća u financiranje. Poduzetnički uzlet grada prepoznat je 2012. godine gdje je časopis Financial Times proglasio Jastrebarsko jednim od Europskih gradova budućnosti Južne regije Europe za 2012. i 2013. godinu i ujedno prvim hrvatskim gradom koji se našao na popisu deset gradova uspješnih u promoviranju strategije za privlačenje direktnih stranih investicija (Vijesti RTL, 2018.). Hrvatsko izdanje časopisa Forbes 2013. godine je po drugi put uvrstilo Jastrebarsko među 20 gradova pokretača Hrvatske (Poslovni savjetnik, 2018.), dok je u Luxembourgu je u kategoriji „Poboljšanje poslovnog okruženja“ Grad Jastrebarsko predstavljao Hrvatsku i osvojio drugo mjesto (lokalni.vecernji.hr, 2018.).

Grad Jastrebarsko pobrinuo se i za potrebe elektroničkih izvoda osobnih podataka i izdavanje e-obrazaca kroz aktivan sustav registracije i autentifikacije građana. Neki od pokazatelja učinka učinkovitije i djelotvornije javne uprave su otvorena sučelja za pristup podacima, katalog unaprjeđenih internih procedura te povezane baze podataka. U procesu realizacije je kiosk za plaćanje računa komunalnih usluga. Još jedan od primjera dobre prakse je geo-informacijski sustav. Na temelju višegodišnjeg iskustva u razvoju programskih rješenja za gradove i općine, tvrtka Promet i prostor d.0.o. izradila je profesionalna programska rješenja za vođenje baze podataka i upravljanje infrastrukturom na području jedinica lokalne samouprave, uključujući i za Grad Jastrebarsko.

\subsection{Pametna mobilnost}

Pokazatelji učinka razvijenog sustava lokalnog javnog prijevoza predstavljaju autobusi na električni pogon ili prirodni plin s ugrađenim GPS-om i mobilnim sustavom dojave položaja i sustavom za primanje zahtjeva dolaska putem mobilne aplikacije. U realizaciji je i uspostava javnog prijevoza za potrebe dostave namirnica i/ili lijekova u udaljena naselja u Gradu Jastrebarskom te unaprjeđenje autobusnih čekaonica s pametnim klupama i digitalnim ekranima. Kako bi se poboljšala javna mobilnost uvedeni su sustavi za nadzor prometa te su u realizaciji mobilne aplikacije koje će pružiti građanima uvid u stanje javnog prijevoza. Na taj način Jastrebarsko se upisalo u mali broj gradova koji nude ovakvu pogodnost svojim sugrađanima, ali i turističku ponudu. U strateškom planu Grada Jastrebarsko je otvaranje još dodatnih četiri električnih punionica za električna vozila. Pilot projekt pametne ulice u Gradu Jastrebarsko obuhvaća primjenu IKT rješenja i aplikacija. Važan aspekt predstavlja primjena Internet stvari poput multifunkcionalne senzorske mreže, Wi-Fi usmjerivačima, senzori za automatsko prepoznavanje vozila te senzorima za temperaturu i vlažnost zraka.

\subsection{Pametni okoliš}

Na području Grada Jastrebarsko otpad se prikuplja na kućnom pragu, zelenim otocima ili reciklažnom dvorištu, a odvojeno se prikupljaju otpadni papir, plastika, staklo, metal, električki i elektronički otpad, baterije, akumulatori, otpadna vozila, gume, ulja, otpadni tekstil, obuća i medicinski otpad. Grad Jastrebarsko poznat je po tome da je jedan od gradova s najvećim postotkom odvajanja otpada te predstavlja dobar primjer pravilnog i odgovornog postupanja s otpadom. Postizanje tog cilja bilo je uz puno odgovornosti lokalne samouprave i puno suradnje i razumijevanja građana. Preduvjet postupanja s otpadom u Jastrebarskom bilo je ozakoniti odlagalište otpada koji je do tada predstavljao izvor neugodnih mirisa, čestih zapaljenja i požara. Grad Jastrebarsko je jedan od prvih gradova koji je sanirao i zatvorio odlagalište otpada, u skladu s važećim zakonskim propisima i na temelju građevinske dozvole.Ubrzo je postavljen 
i veliki broj zelenih otoka koji su mogli primiti derivate poput stakla i tekstila. Uspostavljeno je reciklažno i mobilno reciklažno dvorište u gradu. Veliki problem predstavljao je i odvoz glomaznog otpada, poput odbačenih dijelova namještaja te je Grad Jastrebarsko omogućio besplatni odvoz do tri puta godišnje za sve sugrađane. Također, Grad Jastrebarsko ulaže u postavljanje sustava pametne javne rasvjete i postavljanje sustava pametnog upravljanja vodama putem korištenja Internet stvari, kao i kontrola kvalitete zraka. Važan aspekt je ulaganje $u$ energetski obnovljene zgrade uz naglasak na korištenje obnovljivih izvora energije. Tako je 2014. godine na području Zagrebačke županije izgrađen prvi niskoenergetski objekt „Dječji vrtić Radost". Cilj je bio smanjiti emisije stakleničkih plinova i postići uštedu električne energije putem ugradnje LED rasvjete.

\subsection{Pametni život}

Koncept Smart City zahtijeva odnos s građanima, sugrađanima, dobavljačima i javnim radnicima na temelju transparentnosti, odgovornosti, pravilnog korištenja i potrošnje resursa te rane identifikacije potreba.

Grad Jastrebarsko veliku važnost posvećuje razvoju širokopojasne infrastrukture na prostoru grada. Riječ je o povećanju dostupnosti interneta u dijelovima grada gdje to prije nije bilo omogućeno. U planu je i digitalizacija gradske knjižnice, putem koje bi građanima bio omogućen pristup e-knjigama putem online aplikacija. Također, postavljena je nekolicina računala kako bi građanima bio omogućen besplatan pristup Internetu. Pilot projekt pametnog naselja u Gradu Jastrebarsko potiče izgradnju pametnih pasivnih obiteljskih kuća i kuća baziranih na principima zelene gradnje.U realizaciji je i pametna kartica, „Jastrebarsko e-card“, putem koje će građanima biti omogućeno plaćanje svih usluga grada, od komunalnih usluga, računa, javni prijevoz i brojne druge.

\section{Rezultati istraživanja}

Tablica 1. Spolna zastupljenost ispitanika
Istraživanje je provedeno u rujnu 2020. godine temeljem anketnog upitnika koji se distribuirao elektroničkom poštom građanima Jastrebarskog te putem društvenih mreža. Obuhvat istraživanja je grad Jastrebarsko i okolica. Ispitanici koji su odgovorili putem elektroničke pošte građani su Grada Jastrebarskog $(\mathrm{N}=8)$ te su zatraženi da odgovore na anketni upitnik koji se nalazio u prilogu i time doprinesu rezultatima istraživanjima. Osam ispitanika ispunilo je anketni upitnik, dok dvoje ispitanika nisu odgovorili na anketni upitnik. Sukladno tome, postotak vraćanja anketnog upitnika putem elektroničke pošte iznosio je 80 posto. Ostatak anketnog upitnika ( $\mathrm{N}=121)$ proveden je putem društvenih mreža gdje se tražilo da odgovore daju isključivo građani Grada Jastrebarskog. Uvijek postoji mogućnost subjektivnog odgovaranja prilikom davanja odgovora u anketama, tako da je upitno da li su na anketni upitnik odgovarali samo građani Grada Jastrebarskog. Anketni upitnik sastavljen je na bazi od 21 pitanja. Istraživanje je provedeno online na uzorku od 129 ispitanika. Naravno taj uzorak je relativno malen, ali svejedno dovoljan kako bi se dobila slika približnog stanja i zainteresiranosti hrvatskih građana 0 primjeni pametnih rješenja. Rezultati provedenog istraživanja prikazani su u obliku tablica i slika. Podaci vezani za spolnu zastupljenost, dob i stupanj obrazovanja ispitanika te upoznatost ispitanika s pojmom pametnog grada i utjecaj pametnih rješenja na kvalitetu života prikazani su tabelarno, dok je ostalo provedeno istraživanje prikazano grafički.

\begin{tabular}{|c|c|c|}
\hline Spol & Ženski spol & Muški spol \\
\hline Izraženo u postocima (\%) & 36 & 64 \\
\hline
\end{tabular}

Izvor: autori na osnovu istraživanja. 


\section{Slišković, T., Vrhovec, I.}

Realizacija projekata baziranih na konceptu „pametnih“ gradova u Hrvatskoj s osvrtom na grad Jastrebarsko
Tablica 2. Dob ispitanika

\begin{tabular}{|l|c|c|c|c|c|c|c|c|}
\hline Dob ispitanika & Manje & $18-$ & $25-30$ & $31-40$ & $41-50$ & $51-60$ & Više od 60 \\
\hline Izraženo u postocima (\%) & 2,40 & 18,90 & 52 & 7,10 & 12,60 & 6,30 & 0,80 \\
\hline
\end{tabular}

Izvor: autori na osnovu istraživanja.

Tablica 3. Stupanj obrazovanja ispitanika

\begin{tabular}{|c|c|c|c|}
\hline $\begin{array}{c}\text { Stupanj obrazovanja } \\
\text { ispitanika }\end{array}$ & Srednja stručna sprema & Viša stručna sprema & Visoka stručna sprema \\
\hline Izraženo u postocima (\%) & 29,90 & 29,90 & 40,20 \\
\hline
\end{tabular}

Izvor: autori na osnovu istraživanja.

Tablica 4. Upoznatost ispitanika s pojmom pametnog grada

\begin{tabular}{|c|c|c|}
\hline $\begin{array}{c}\text { Upoznatost ispitanika s pojmom } \\
\text { pametnog grada }\end{array}$ & Da & Ne \\
\hline Izraženo u postocima (\%) & 65,40 & 34,60 \\
\hline
\end{tabular}

Izvor: autori na osnovu istraživanja.

Tablica 5. Utjecaj pametnih rješenja na kvalitetu života

\begin{tabular}{|c|c|c|c|c|}
\hline $\begin{array}{c}\text { Utjecaj pametnih rješenja na } \\
\text { kvalitetu života }\end{array}$ & $\begin{array}{c}\text { Ispitanici smatraju da } \\
\text { pametna rješenja utječu na } \\
\text { kvalitetu života }\end{array}$ & $\begin{array}{c}\text { Ispitanici ne znaju da li } \\
\text { postoji utjecaj pametnih } \\
\text { rješenja na kvalitetu života }\end{array}$ & $\begin{array}{c}\text { Ispitanici smatraju da } \\
\text { pametna rješenja ne utječu } \\
\text { na kvalitetu života }\end{array}$ \\
\hline Izraženo u (\%) & 88,90 & 11,10 & 0 \\
\hline
\end{tabular}

Izvor: autori na osnovu istraživanja.
Prvenstveno je ispitano mišljenje ispitanika o tome što koncept pametnog grada točno predstavlja, a distribucija njihovih odgovora prikazana je na Slici 2.

Iz Slike 2. je vidljivo kako najveći postotak ispitanika (njih čak 36,7\%) smatra kako koncept pametnog grada predstavlja prvenstveno pametno korištenje energije, a nešto manji postotak (32\%) ispitanika smatra kako je pametni grad urbana sredina usredotočena na građane. Najmanji broj
Slika 2. Opis koncepta pametnog grada

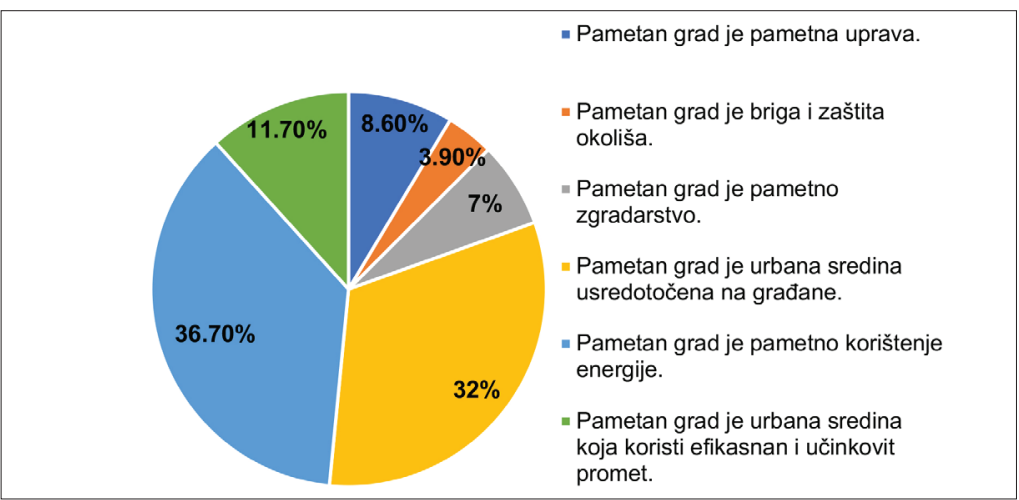

Izvor: autori na osnovu istraživanja. 
Slika 3. Ključna područja za koja se smatra da inicijativa pametnog grada može značajnije poboljšati ili unaprijediti

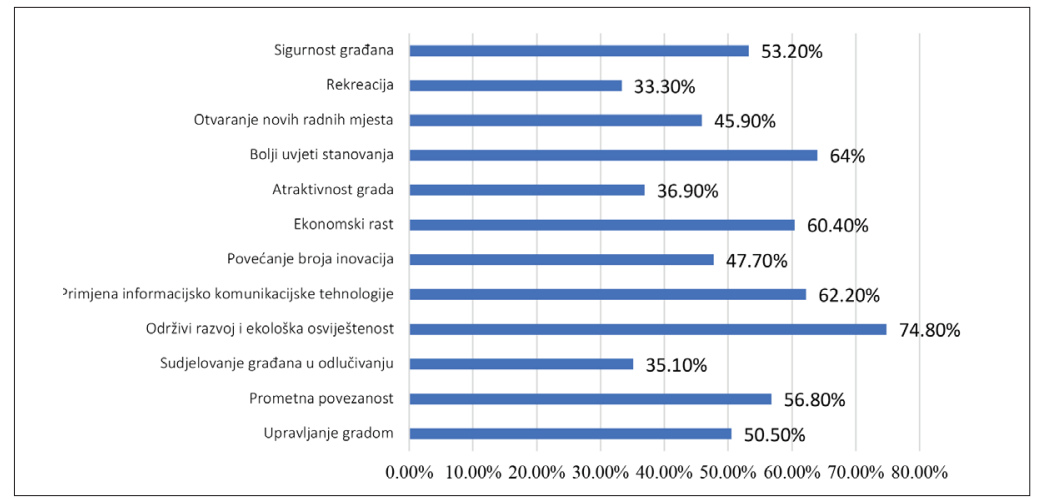

Izvor: autori na osnovu istraživanja.

ispitanika smatra kako je pametan grad briga i zaštita okoliša.

Na pitanje smatraju li Grad Jastrebarsko pametnim gradom, neočekivano velik udio sudionika $(45,5 \%)$ odgovorilo je kako smatraju kako Grad Jastrebarsko nije pametan grad, što ukazuje na lošu informiranost ispitanika o konceptu pametnog grada. Ipak, veći udio ispitanika na pitanje je odgovorio potvrdno.

Sljedeće pitanje u upitniku bilo je usmjereno na mišljenje ispitanika o tome koja su ključna područja za koje smatraju da in inicijativa pametnog grada može značajnije poboljšati ili unaprijediti. Pokazalo se kako je potreban veliki pomak gradova prema ulaganju u zaštitu okoliša i ekosistema. Konkretno, 74,8\% ispitanika smatra kako je najvažnija inicijativa koju bi grad trebao poboljšati inicijativa održivog razvoja i ekološke osviještenosti. Rezultati ukazuju na to kako postoji i velika potreba unaprjeđenja inicijativa poput boljih uvjeta stanovanja (64\%), primjene informacijsko komunikacijske tehnologije (62,2\%) i ekonomski rast $(60,4 \%)$. Također, ispitanici smatraju kako inicijative pametnog grada mogu unaprijediti područja poput prometne povezanosti, sigurnosti građana, upravljanja gradom, povećanja broja investicija i otvaranje novih radnih mjesta. Manje značajnim područjima mogućeg unaprjeđenja smatraju se područja rekreacije (33,3\%), sudjelovanje građana u odlučivanju $(35,1 \%)$ i

Slika 4. Čimbenici koji predstavljaju najveći utjecaj na kvalitetu života u gradovima

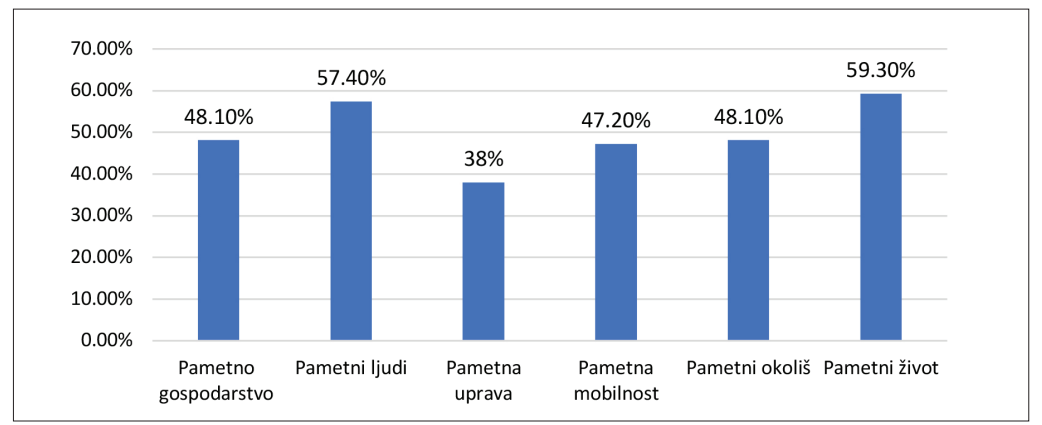

Izvor: autori na osnovu istraživanja. 
Slišković, T., Vrhovec, I.

Realizacija projekata baziranih na konceptu „pametnih“ gradova u Hrvatskoj s osvrtom na grad Jastrebarsko

Slika 5. Investiranje u pametno gospodarstvo

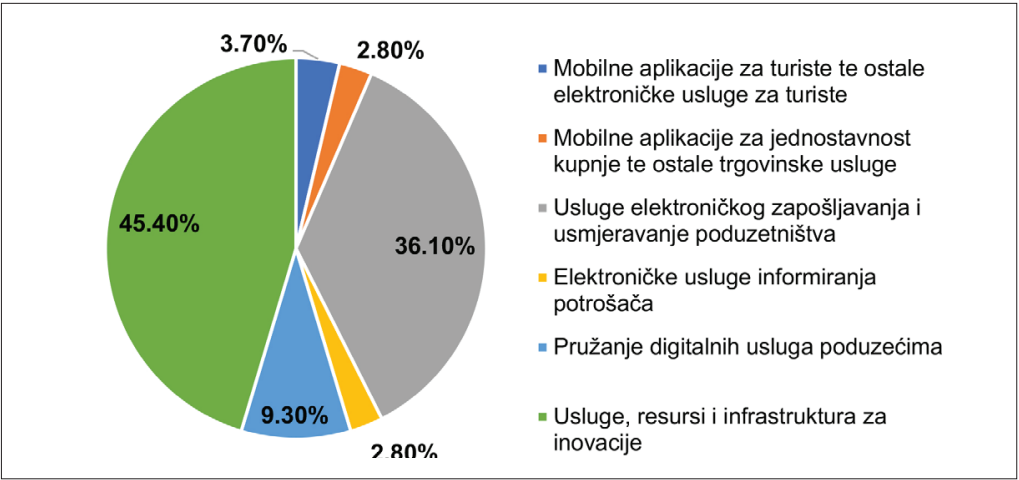

Izvor: autori na osnovu istraživanja.

atraktivnost grada (35,1\%) (Slika 3.).

Kod ispitivanja mišljenja o značajnosti pojedinih čimbenika pametnog grada, može se zaključiti kako upravo ljudi su ti koji predstavljaju najbitniji čimbenik za poboljšanje kvalitete života. Rezultati pokazuju kako pametan život $(59,3 \%)$ i pametni ljudi (57\%) predstavljaju najbitnije čimbenike za kvalitetu života. Za pametnu se upravu smatra kako ima najmanji utjecaj od ostalih čimbenika na kvalitetu života u gradovima (Slika 4.).

Slika 5. prezentira prisutnu percepciju ispitanika o potrebi investiranja u određene segmente koji spadaju u čimbenike pametnog gospodarstva.Prema dobivenim rezultatima iz provedenog istraživanja, usluge, resursi i infrastruktura predstavljaju najveću potrebu građana za ulaganjem (45,4\%). $\mathrm{Na}$ drugom mjestu nalaze se usluge elektroničkog zapošljavanja i usmjerivanje poduzetništva (36,1\%). Prema ispitanicima, najmanje potrebe za ulaganje su u mobilne aplikacije za jednostavnost kupnje te ostale trgovinske usluge, elektroničke usluge informiranja potrošača i mobilne aplikacije za turiste te ostale elektroničke usluge za turiste.

Kod potrebe za ulaganjem u komponente faktora pametnih ljudi (Slika 6.), rezultati ispitivanja pokazuju kako savjeti i osposobljavanje u novim tehnologijama (edukacije građana) predstavljaju najveću potrebu građana za ulaganjem (64,8\%). Ističe se i važnost investicije u lokalnu platformu kolektivne suradnje za gradske izazove (26,9\%), dok investicija u lokalnu platformu za skupno financiranje predstavlja najmanju važnost $(8,3 \%)$.

Slika 7. ilustrira rezultate mišljenja o važnosti investiranja u pojedina područja koja spadaju

Slika 6. Investiranje u pametne ljude

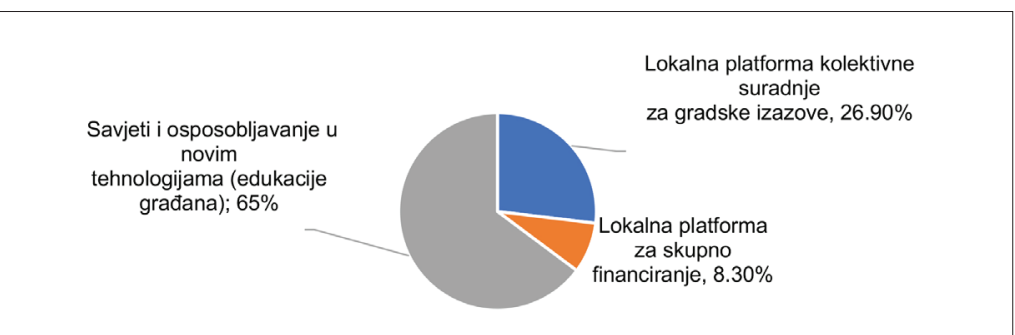

Izvor: autori na osnovu istraživanja. 


\begin{tabular}{|l|l|} 
"Portali transparentnosti i društveni \\
mediji
\end{tabular}

Izvor: autori na osnovu istraživanja.

pod čimbenik pametne uprave. Prema dobivenim rezultatima, strateški plan i pametni plan grada predstavljaju daleko najveću potrebu građana za ulaganjem (63,8\%). Drugo područje za investiranje, prema ispitanicima, predstavljaju portali transparentnosti i društveni mediji (16,20\%).

$S$ aspekta potreba investiranja u pametnu mobilnost (Slika 8.), pristupačnost i jednostavnost prometne infrastrukture $(54,60 \%)$ predstavljaju najveću potrebu građana za ulaganjem. Prema ispitanicima, najmanje je potrebno ulagati u mobilnu pokrivenost (5,6\%), upravljanje mrežom javnih bicikla, upravljanje parkingom, upravljanje semaforima i semaforskim uređajima (po 4,6\%) i upravljanje mjestima za punjenje električnih vozila $(2,8 \%)$.

Slika 9. ilustrira percepciju građana Jastrebarskog o potrebi investiranja u komponente pametnog okoliša. Prema dobivenim rezultatima u provedenom istraživanju, potrošnja i kvaliteta vode te upravljanje mrežom za saniranje i obradu otpadnih voda Važan aspekt predstavlja i čišćenje

Slika 8. Investiranje u pametnu mobilnost

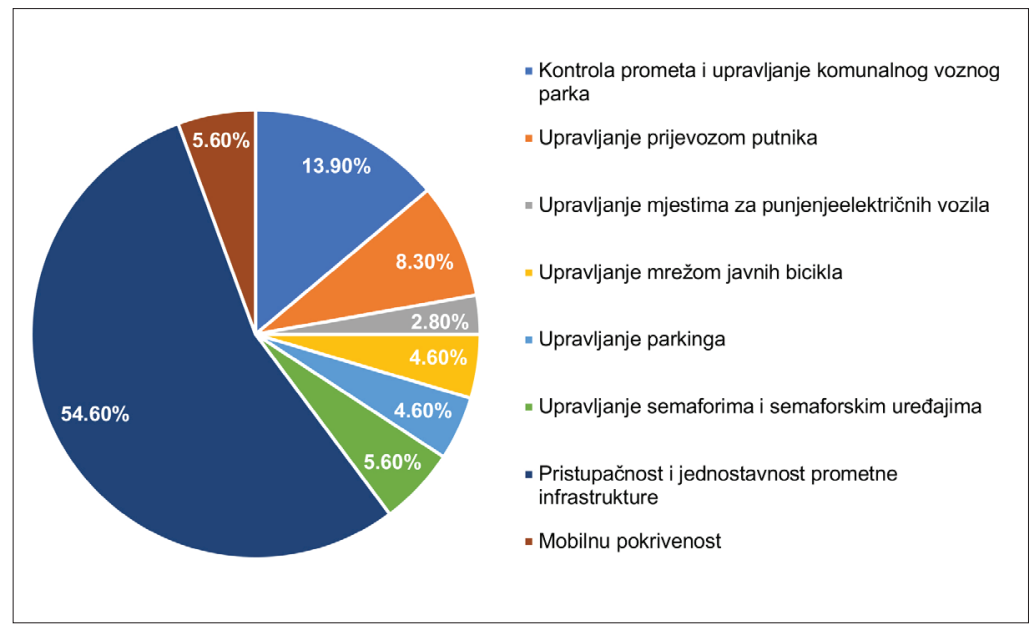

Izvor: autori na osnovu istraživanja.

Slišković, T., Vrhovec, I.

Realizacija projekata baziranih na konceptu „pametnih" gradova u Hrvatskoj s osvrtom na grad Jastrebarsko 
Slišković, T., Vrhovec, I.

Realizacija projekata baziranih na konceptu „pametnih“ gradova u Hrvatskoj s osvrtom na grad Jastrebarsko

Slika 9. Investiranje u pametan okoliš

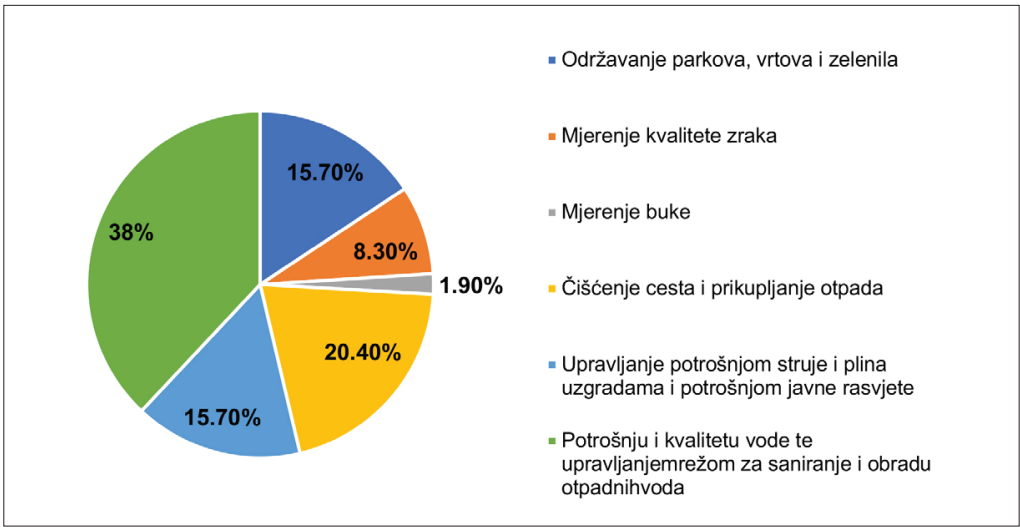

Izvor: autori na osnovu istraživanja.

cesta i prikupljanje otpada, održavanje parkova, vrtova i zelenila te upravljanje potrošnjom struje i plina u zgradama i potrošnjom javne rasvjete. Relativno manji postotak (8,3\%) ispitanika smatra kako je potrebno uložiti u mjerenje kvalitete zraka, dok je samo dvoje ispitanika $(1,90 \%)$ odgovorilo kako smatra da je potrebno investirati u mjerenje buke.

Ispitivanje stava o potrebi ulaganja u komponente pametnog života je pokazalo kako urbanističko planiranje i stanovanje $(40,7 \%)$ te imovinska i informatička sigurnost (38\%) predstavljaju najveću potrebu građana za ulaganjem. Rezultati (Slika 10.) ukazuju na to da je najmanja potreba za ulaganjem u području socijalnih pitanja poput telefonske pomoći i ostalih elektroničkih usluga.

Drugi dio upitnika odnosio se na ocjenu zadovoljstva građana pojedinim aspektima života u gradu Jastrebarskom. Iz rezultata prezentiranih na Slici 11. se može zaključiti kako su građani uglavnom zadovoljni i sa životom u gradu, lakoćom pronalaska posla u gradu, kvalitetom zgrada, razinom komunalnih usluga i dostupnošću tehnologije. Najveći udio ispitanih je potpuno zadovoljan životom u gradu $(38,53 \%)$, te zatim kvalitetom zgrada (31\%), lakoćom pronalaska posla (22,94\%), dostupnošću tehnologije $(22,0 \%)$ i razinom komunalnih usluga u gradu (19,2\%). Samo tri ispitanika (2,75\%) nezadovoljno je životom u gradu, dok najveće nezadovoljstvo iskazuju

Slika 10. Investiranje u pametan život

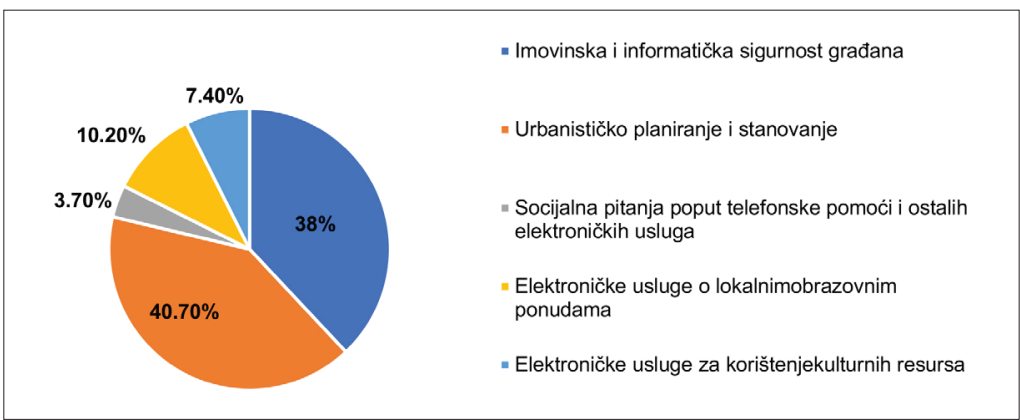

Izvor: autori na osnovu istraživanja. 
Slika 11.Zadovoljstvo građana

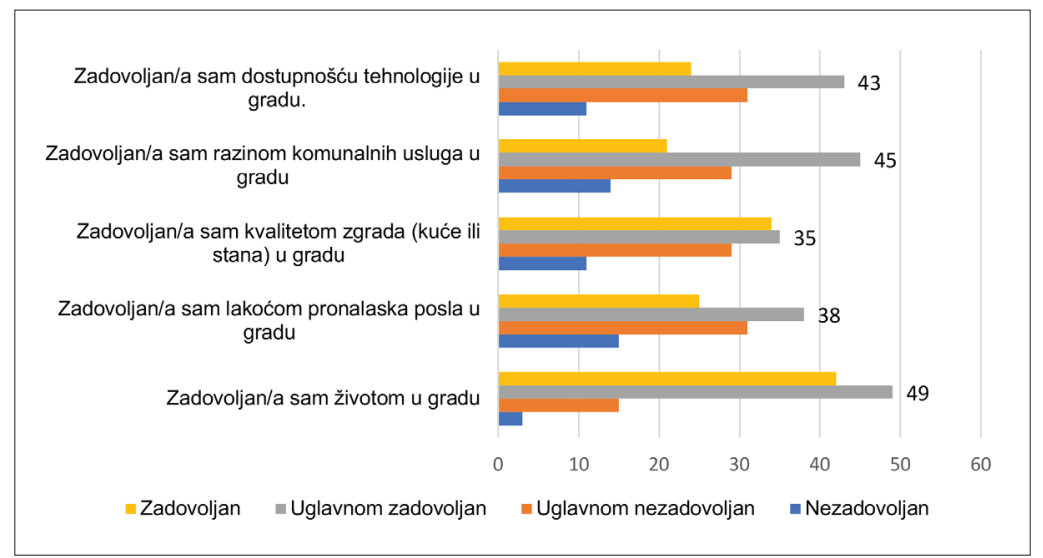

Izvor: autori na osnovu istraživanja.

u lakoći pronalaska posla $(13,76 \%)$ i razinom komunalnih usluga u gradu (12,84\%). Uvidom u dobivene rezultate, gradovi se mogu fokusirati na unaprjeđenje ili poboljšanje čimbenika koji potiču nezadovoljstvo među građanima, poput ulaganja u zapošljavanje i podizanja razine komunalnih usluga, paralelno s održavanjem čimbenika koji potiču zadovoljstvo građana, poput života u gradu.

Naredna faza istraživanja bila je usmjerena na stavove građana vezane uz komunikaciju s gradskom upravom. Preko $71 \%$ ispitanika izrazilo je želju za češćom komunikacijom s gradskom upravom u svrhu obavještavanja, nešto više od $8 \%$ se negativno izrazilo po tom pitanju, dok preostali udio ispitanika nije siguran kako bi se očitovao 0 toj potrebi. Pri odabiru načina pružanja željenih informacija, rezultati su pokazali kako bi ispitanici najviše htjeli biti obaviješteni preko društvenih kanala (39\%) i putem internetskih portala grada (38,9\%). 19,4\% ispitanika želi obavijesti dobiti putem e-maila, dok niti jedan ispitanik ne želi da se informiranje vrši putem letaka i plakata. Nešto manje od $2 \%$ ispitanika odgovorilo je kako ne želi biti uopće obaviješteno niti jednim od ponuđenih kanala.

Najveća zainteresiranost ispitanika za obavještavanje o područjima gradske uprave, veže se za europske i nacionalne fondove (62\%) i zaštitu

Slika 12. Područja gradske uprave o kojima ispitanici žele biti obaviješteni

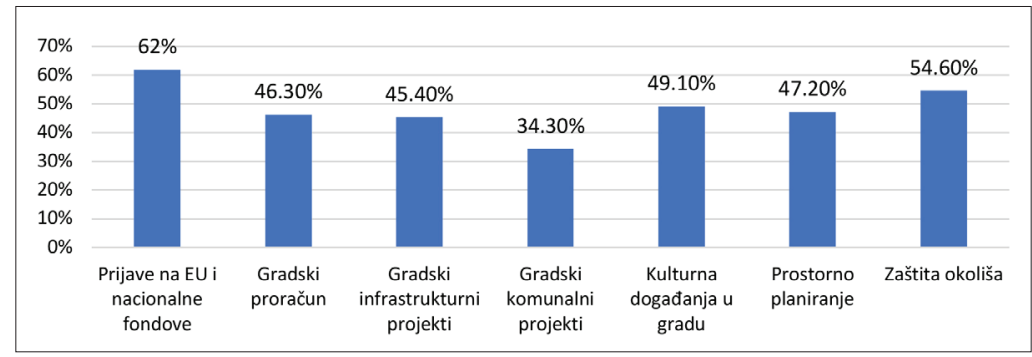

Izvor: autori na osnovu istraživanja. 
Slišković, T., Vrhovec, I.

Realizacija projekata baziranih na konceptu „pametnih“ gradova u Hrvatskoj s osvrtom na grad Jastrebarsko

Slika 13. Analiza kompetencija i zainteresiranosti ispitanika

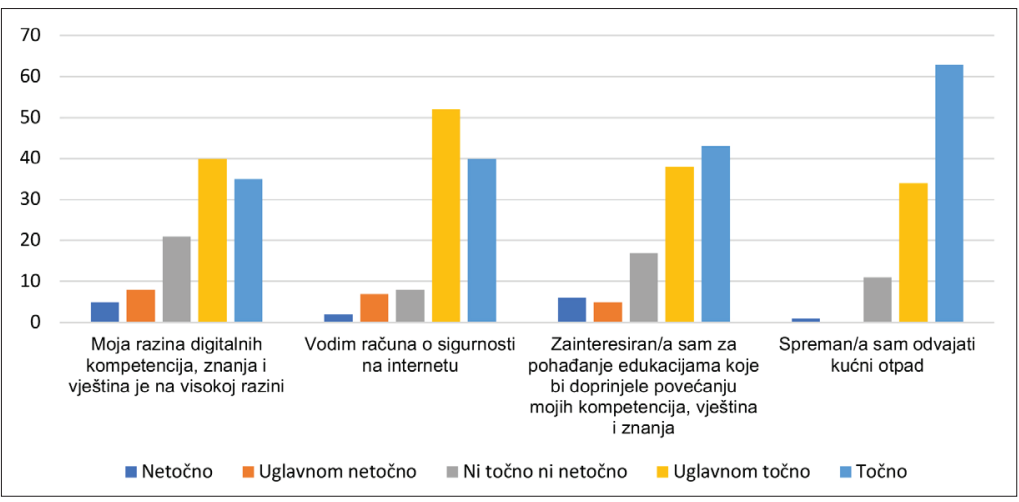

Izvor: autori na osnovu istraživanja.

okoliša (54,6\%). Rezultati (Slika 12.) ukazuju kako građani također žele biti obaviješteni i informirani o kulturnim događanjima, prostornom planiranju, gradskom proračunu, i gradskim infrastrukturnim projektima. Najmanja zainteresiranost ispitanika je 0 gradskim komunalnim projektima (34,90\%). Iz navedenog, može se ustanoviti da želja ispitanika o brizi i zaštiti okoliša postaje s godinama sve veća i veća.

Vrlo značajan rezultat proizlazi iz dijela upitnika u kojem je ispitana volja ispitanika o sudjelovanju u procesu odlučivanja putem digitalne platforme, ukoliko bi im to bilo omogućeno. Rezultati su pokazali kako bi većina ispitanika $(76,10 \%)$, ukoliko bi imala mogućnost sudjelovanja u procesu odlučivanja putem digitalne platforme, konkretno mobilne aplikacije koja omogućava sudjelovanje u javnim raspravama, glasanje o inicijativama i davanja prijedloga gradskoj upravi, iskoristila tu priliku. To definitivno predstavlja poticaj gradovima za razvoj takvih aplikacija.

$U$ finalnom dijelu ankete ispitana je percepcija o vlastitim kompetencijama i zainteresiranosti ispitanika o unapređenju istih. Utvrđeno je kako su ispitanici u većem dijelu informatičko pismeni, odnosno da imaju dobru digitalnu razinu kompetencija, znanja i vještina. Samo $11,93 \%$ ispitanika smatra da nema potrebne vještine, 19,26\% smatra da imaju srednju razinu, dok čak $68,81 \%$ ispitanika smatra da su njihove kompetencije na visokoj razini. Analizom je također utvrđeno da većina ispitanika $(84,4 \%)$ vodi računa o sigurnosti na internetu te da postoji velika zainteresiranost $(74,31 \%)$ za pohađanje edukacija koje bi doprinosile povećanju njihovih kompetencija, znanja i vještina. Što se tiče volje za odvajanjem otpada, samo jedan ispitanik (0,92\%) je odgovorio kako nema želje za odvajanjem kućnog otpada, $10 \%$ ispitanika nije sigurno, dok je 88,99\% ispitanika spremno odvajati kućni otpad (Slika 13.).

\section{Zaključak}

$S$ razvojem i transformacijom globalnih pametnih gradova u prošlosti su se uglavnom razmatrale prilike na međunarodnom tržištu i industrijska konkurentnost, no posljednjih godina razvoj globalnih pametnih gradova fokusirao se na rješavanje lokalnih problema, zapravo poboljšanje gradskog poslovanja i problema vezanih uz život, te u potpunosti iskorištavanje lokalne gradnje. Cjelokupni dizajn mehanizma zahtijeva razmišljanje o izgradnji aplikacijskog ekosustava za korisnike stvarnih poslovnih operacija. Iz međunarodnih trendova i promjena u razvoju, pametna gradska rješenja moraju istaknuti i riješiti probleme, uistinu zadovoljiti potražnju i stvarati vrijednost. U Hrvatskoj postoji još dosta mjesta za napredak, te bi gradovi trebali ulagati svoje napore za izgradnjom još bolje kvalitete života. Hrvatski gradovi se polako okreću k digitalizaciji i optimizaciji usluga 
građana te su, kao što je u članku vidljivo, veliki broj pametnih rješenja je implementirano ili u procesu realizacije. Hrvatski gradovi imaju na razmatranju razne alate za interaktivnu digitalnu komunikaciju s građanima o pojedinim podacima. Potrebno je razviti odnos prema građanima kroz digitalne platforme te aktivno uključiti građane u život grada kroz različite inovativne, tehnološki zanimljive i kreativne oblike. Također, potrebna je primjena vrlo kompleksnih digitalnih senzorskih sustava koji mogu prikupljati velike količine podataka, na udaljeni načine upravljati infrastrukturom i raditi to tako da što bolje i maksimalno upotrijebe resurse s kojima raspolažu kako bi poboljšali zadovoljstvo i kvalitetu života građana. Pametni gradovi trebaju se temeljiti na kreativnosti znanja, kreativnosti stanovnika i digitalnoj infrastrukturi. Kroz prikupljanje podataka i informacija i izgradnju modela može se ostvariti racionalna koordinacija resursa i građanima omogućiti bolji životni prostor. Povećanjem standarda, otvara se prostor i za povećanje svjesnosti ljudi o očuvanju okoliša. Pogotovo u manjim sredinama, kao što je Jastrebarsko, građani su više poistovjećeni s okolinom nego u nekim većim gradovima. Na taj način, svijest građana dolazi više do izražaja i onda dolazi do pomaka. U biti, pametni gradovi bi trebali pružiti novi pogled na gradove, naglašavajući građane, koji su najvažniji dio njega. Sukladno tome, jedan od glavnih ciljeva tih gradova trebao bi biti da urbano okruženje bude integriranije s građanima.

\section{Literatura}

Atlee, T., Por, G. (2000) Collective intelligence as a field of multi-disciplinary study and practice. En ligne.< http://www. community-intelligence. com/files/Atlee [30.9.2020.].

Batty, M.,Axhausen, K.W., Giannotti,F.,Pozdnoukhov,A., Bazzani,A., Wachowicz, M., Ouzounis, G., Portugali, Y. (2012) Smart cities of the future. The European Physical Journal Special Topics, 214(1): 481-518.

Brčić, D., Slavulj, M., Ćosić, M. (ur.) (2017) Indikatori mobilnosti u konceptu" Smart City". Zbornik s okruglog stola. Fakultet prometnih znanosti, Sveučilište u Zagrebu.

Burazer, B. (2012) Normizacija u procesu kreiranja „pametnih gradova “. Zagreb: Hrvatski zavod za norme. Dostupno na: https:/www.hzn.hr/UserDocslmages/pdf/Normizacija\%20u\%20procesu\%20kreiranja\%20 pametnih\%20gradova.pdf [1.10.2020.].

European Commision. What are smart cities? Dostupno na: https://ec.europa.eu/info/eu-regional-andurban-development/topics/cities-and-urban-development/city-initiatives/smart-cities_en [5.10.2020.].

De Guimarães, J. C. F., Severo, E. A., Júnior, L. A. F., Da Costa, W. P. L. B., Salmoria, F. T. (2020). Governance and quality of life in smart cities: Towards sustainable development goals. Journal of Cleaner Production, 253: 119926.

Fond za zaštitu okoliša i energetsku učinkovitost. Javni poziv za sufinanciranje projekata primjene koncepta „pametnih gradova i općina“. Dostupno na https://www.fzoeu.hr/docs/javni_poziv_za_ sufinanciranje_projekata_primjene_koncepta_pametnih_gradova_i_opcina_v1.pdf [3.10.2020.].

Giffinger, R.,Pichler-Milanović, N.(2007) Smart cities: Ranking of European medium-sized cities. Centre of Regional Science, Vienna University of Technology.

Giffinger, R., Haindlmaier, G., \& Kramar, H. (2010) The role of rankings in growing city competition. Urban Research \& Practice, 3(3): 299-312.

IBM Global Business Services. A vision of smarter cities. Dostupno na: https://www.ibm.com/downloads/ cas/2JYLM4ZA [7.10.2020.]. 


\section{Slišković, T., Vrhovec, I.}

Realizacija projekata baziranih na konceptu „pametnih“ gradova u Hrvatskoj s osvrtom na grad Jastrebarsko
Jastrebarsko.hr Strategija razvoja pametnog Grada Jastrebarsko 2019. - 2024. Smart City Jastrebarsko. Dostupno na: http://jastrebarsko.hr/download/javna-rasprava-o-nacrtu-strategije-razvoja-pametnoggrada-jastrebarskog-_19_03.pdf [6.10.2020.].

Lokalni.vecernji.hr (2018) Gradovi. Dostupno na: https://lokalni.vecernji.hr/gradovi/casopisfinancialtimesa-dodijelit-ce-jastrebarskom-pocasnu-nagradu-za-web-strategiju-3094 [20.11.2020.].

Ministarstvo regionalnoga razvoja i fondova Europske unije.Proces izrade nacionalne razvojne strategije do 2030. godine. Dostupno na: https://udruge.gov.hr/UserDocsImages/dokumenti/Proces\%20izrade\%20 Nacionalne\%20razvojne\%20strategije\%20do\%202030.\%20godine.pdf [8.10.2020.].

Poslovni dnevnik.Pametni gradovi 2019. - o projektu.Dostupno na: https://www.poslovni.hr/poduzetnik/ pametni-gradovi-2019-o-projektu-353789 [30.9.2020.].

Poslovni savjetnik.com (2018) Aktualno. Dostupno na: http://www.poslovnisavjetnik.com/aktualno/ izabrao-forbes-jastrebarsko-grad-koji-pokrece-hrvatsku [20.11.2020.].

Schuurman, D., Baccarne, B., De Marez, L., Mechant, P. (2012) Smart ideas for smart cities: Investigating crowdsourcing for generating and selecting ideas for ICT innovation in a city context. Journal of theoretical and applied electronic commerce research, 7(3): 49-62.

Škrlec, D. (2017) Pametni gradovi - budućnost ili stvarnost?. Dostupno na: https://www.davor-skrlec.eu/ pametni-gradovi-buducnost-ili-stvarnost/ [1.10.2020.].

Vijesti.rtl.hr. Novosti. (2018) Dostupno na: https://vijesti.rtl.hr/novosti/289702/jastrebarsko-jeeuropskigrad-buducnosti/ [19.11.2020.]. 

